Piotr Merks ${ }^{1,3,4,5,6}$, Damian Świeczkowski2,4, Krzysztof Bilmin' ${ }^{1}$, Marta Jakubowska ${ }^{4}$, Ewelina Drelich ${ }^{4}$, Jędrzej Lewicki ${ }^{4}$, Wioletta Golębiewska ${ }^{4}$, Joanna Bogusz ${ }^{7}$, Milosz Jaguszewski ${ }^{2}$

\title{
COMMUNITY PHARMACY DURING THE COVID-19 PANDEMIC: A CROSS-SECTIONAL STUDY
}

\section{APTEKI OGÓLNODOSTĘPNE W CZASIE PANDEMII COVID-19: BADANIE PRZEKROJOWE}

${ }^{1}$ Collegium Medicum, Cardinal Stefan Wyszyński, University Faculty of Medicine; Warsaw, Poland Collegium Medicum, Uniwersytet Kardynała Stefana Wyszyńskiego, Wydział Medyczny; Warszawa, Polska ${ }^{2}$ Medical University of Gdańsk, First Department of Cardiology, Gdańsk, Poland Gdański Uniwersytet Medyczny, I Katedra i Klinika Kardiologii, Gdańsk, Polska ${ }^{3}$ Collegium Medicum in Bydgoszcz, Department of Pharmaceutical Technology, Poland Collegium Medicum w Bydgoszczy, Katedra Technologii Postaci Leku, Bydgoszcz, Polska

${ }^{4}$ Polish Pharmaceutical Group, Łódź, Poland

Polska Grupa Farmaceutyczna, Łódź, Polska

${ }^{5}$ Trade Union of Pharmacy Workers, Warsaw, Poland

Związek Zawodowy Pracowników Farmacji, Warszawa, Polska

${ }^{6}$ Employed Pharmacist in Europe (EPhEU) c/o Verband Angestellter Apotheker Österreichs (VAAÖ)

Berufliche Interessenvertretung, Vienna, Austria

Employed Pharmacist in Europe (EPhEU) c/o Verband Angestellter Apotheker Österreichs (VAAÖ) Berufliche Interessenvertretung, Wiedeń, Austria

${ }^{7}$ National Institute of Public Health - National Institute of Hygiene, Department of Epidemiolog of Infectious

Diseases and Surveillance Warsaw, Poland

Narodowy Instytut Zdrowia Publicznego - Państwowy Zakład Higieny, Zakład Epidemiologii Chorób

Zakaźnych i Nadzoru, Warszawa, Polska

\section{ABSTRACT}

INTRODUCTION. The COVID-19 pandemic has proved that community pharmacies play a pivotal role in providing medicines, information and safety measures to prevent the spread of SARS-CoV-2.

PURPOSE. The study aimed to get to know opinions of pharmacy staff and owners on the functioning of the community pharmacy during the outbreak of the COVID-19 pandemic.

MATERIALS AND METHODS. To collect opinions about functioning of the community pharmacy during the pandemic, we conducted cross-sectional study among pharmacy staff and owners of pharmacies.

RESULTS. The study group included 456 respondents mostly associated with independent pharmacies (55.7\%), from cities less than 100,000 inhabitants (38.8\%). The number of patients as well as filled prescriptions increased during the pandemic. Respondents provided patients with advice on cold (81.6\%), sore throat $(77.0 \%)$ and acherelated complaints (68.6\%). Most of participants (64.5\%) declared that they informed patients about COVID-19. The safety measures in community pharmacies included: a safety regulations poster during the pandemic (97.1\%), handwashing in accordance with recommended guidelines (96.3\%) and using protective gloves by the pharmacy staff (89.9\%). According to $60.7 \%$ of participants, the community pharmacy was properly prepared for the pandemic by the owner, however, respondents from independent pharmacies indicate this more frequently $(\mathrm{p}=0.0001)$.

CONCLUSIONS. Respondents are aware of the role of community pharmacies in the healthcare system during the pandemic, nevertheless, more attention needs to be paid by public authorities and governmental institutions to patient safety in the community pharmacy.

Keywords: community pharmacy; pharmacist; COVID-19; pharmaceutical care; epidemiology 


\section{STRESZCZENIE}

WPROWADZENIE. Pandemia COVID-19 pokazała, że apteki otwarte odgrywają kluczową rolę w zapewnieniu dostępu do leków, informacji i środków bezpieczeństwa w celu zapobiegania rozprzestrzenianiu się SARSCoV-2.

CEL. Celem badania było poznanie opinii pracowników i właścicieli aptek na temat funkcjonowania apteki otwartej w okresie pandemii COVID-19.

MATERIALY I METODY. W celu zebrania opinii na temat funkcjonowania aptek otwartych w czasie pandemii, przeprowadziliśmy badanie przekrojowe wśród pracowników aptek i ich właścicieli.

WYNIKI. W badaniu wzięło udział 456 respondentów, głównie związanych z aptekami prywatnymi (55,7\%), z miast poniżej 100000 mieszkańców (38,8\%). W trakcie pandemii wzrosła liczba pacjentów i zrealizowanych recept. Respondenci udzielali pacjentom porad dotyczących przeziębienia $(81,6 \%)$, bólu gardła $(77,0 \%)$ i innych dolegliwości bólowych (68,6\%). Większość badanych (64,5\%) zadeklarowała, że dostarczyła pacjentom informacji o COVID-19. Środki bezpieczeństwa stosowane w aptekach otwartych obejmowały: plakat prezentujący przepisy bezpieczeństwa zalecane w czasie pandemii (97,1\%), mycie rąk zgodnie z wytycznymi (96,3\%) oraz używanie rękawic ochronnych przez personel apteki $(89,9 \%)$. Według 60,7\% badanych apteka została odpowiednio przygotowana do pandemii przez właściciela; taka odpowiedź była częściej deklarowana przez pracowników aptek prywatnych $(\mathrm{p}=0,0001)$.

WNIOSKI. Respondenci są świadomi roli aptek otwartych w systemie opieki zdrowotnej w okresie pandemii, niemniej jednak władze publiczne i instytucje rządowe powinny poświęcić więcej uwagi bezpieczeństwu pacjentów w aptece otwartej.

Słowa kluczowe: apteki ogólnodostępne, farmaceuta, COVID-19, opieka farmaceutyczna, epidemiologia

\section{INTRODUCTION}

The COVID-19 pandemic has significantly changed how community pharmacists fulfill their responsibilities (1). Clinical pharmacists serving in respiratory units have had to rapidly adapt to a greater number of patients. They have also had to collect information on COVID-19 pharmacotherapy to minimize potential harmful effects for patients stemming from unnecessary treatment and treatment delays due to a lack of good quality evidence (2). Keeping up with the onslaught of information should be considered one of the most important tasks of clinical pharmacists due to the constant shortage of nurses and physicians, who are directly involved in the treatment of patients (3).

The vital role of pharmacists is also seen in community pharmacies. Pharmacists are encouraged to educate patients in terms of protective measures to minimize the risk of contamination, e.g. handwashing, disinfection and personal hygiene, and social distancing (4). Pharmacists are able to differentiate COVID-19 from other infections. Based on their recommendations, some patients can be more easily diagnosed and referred to professional care to confirm COVID-19.1 Pharmacy staff should also encourage chronically ill patients to continue longterm therapy. High adherence to therapy is strongly recommended, because well-managed chronic diseases have been associated with a good prognosis in chronically-ill patients that contract COVID-19 (5).

\section{WSTĘP}

Pandemia COVID-19 istotnie zmieniła sposób pracy farmaceutów w aptekach otwartych (1) i klinicznych. Farmaceuci kliniczni pracujący na OIT musieli szybko przystosować się do zwiększonej liczby pacjentów. Konieczne stało się zbieranie przez nich informacji na temat farmakoterapii w COVID-19, aby ograniczyć występowanie u pacjentów potencjalnie szkodliwych efektów wynikających z wdrożenia niepotrzebnego leczenia lub opóźnień w leczeniu spowodowanych brakiem potwierdzonej skuteczności leczenia w badaniach naukowych(2). Bycie na bieżąco $\mathrm{z}$ aktualnościami $\mathrm{w}$ natłoku informacji powinno być uważane za jedno z najważniejszych zadań farmaceutów klinicznych, ze względu na ciągły brak pielęgniarek i lekarzy, którzy są bezpośrednio zaangażowani w leczenie pacjentów (3).

Istotną rolę farmaceutów w okresie pandemii COVID-19 dostrzega się również w aptekach otwartych. Zachęca się ich, aby edukowali pacjentów w zakresie stosowania środków ochronnych minimalizujących ryzyko zakażenia, takich jak: mycie rąk, dezynfekcja i higiena osobista, oraz zachowanie dystansu społecznego (4). Farmaceuci są w stanie odróżnić COVID-19 od innych infekcji. Na podstawie ich zaleceń niektórzy pacjenci mogą być szybciej diagnozowani i skierowani do specjalistów w celu potwierdzenia zachorowania na COVID-19 (1). Pracownicy aptek powinni również zachęcać pacjentów przewlekle chorych do kontynuowania leczenia długoterminowego. Zaleca się, aby 
Pharmacists have been obliged to adopt a series of changes in their workflow and to rapidly adapt to new circumstances. Apart from the clinical significance of these changes, they may have an impact on the financial stability of community pharmacies: from the increased number of patients at the beginning of the pandemic that led to work overload to the limited number of patients once the epidemic reached its peak $(6,7)$.

\section{AIM}

Thus, this study aimed to collect the opinions of pharmacy staff and owners on the functioning of the community pharmacy during the outbreak of the COVID-19 pandemic.

\section{MATERIALS AND METHODS}

\section{Study design and participants}

This study is a cross-sectional online survey conducted in Poland from the beginning of the SARSCoV-2 outbreak through the peak of the pandemic to the moment when the number of active cases significantly decreased (27 March - 6 May). It was a pilot study focused on pharmacy staff (pharmacists, pharmacy technicians, trainees) and owners, among whom were people without formal pharmaceutical qualifications.The survey was acknowledged by Research Ethical Committee, but is not required for this type of study. . Respondents were informed about the aim of the study in a short statement at the beginning of the questionnaire, and full anonymity was ensured. Respondents who filled the questionnaire were considered to have provided informed consent for study participation (8). The questionnaire was distributed via social media (Facebook) and websites dedicated to pharmacy staff. Participants were able to consult all remarks with the members of the research team throughout the whole study.

\section{Questionnaire development}

The questionnaire was prepared by the research team after an extensive evaluation of the literature, focusing particularly on recently published articles on the pandemic. Volunteers, academicians experienced in social pharmacy studies, and pharmacists with long-term practice in community pharmacy evaluated the questionnaire in terms of face and content validity. Readability was evaluated based on the Gunning Fog Index to ensure that the questionnaire would be easily understood by the respondents, considering their expected level of education.

The final version of the questionnaire consisted of three sections. The first one collected pacjenci przestrzegali zaleceń terapeutycznych, ponieważ odpowiednie leczenie chorób przewlekłych wiąże się z dobrym rokowaniem u pacjentów , u których wystąpi COVID-19 (5).

Farmaceuci muszą wprowadzać szereg zmian w swoim systemie pracy i szybko przystosowywać się do nowych okoliczności. Oprócz klinicznego znaczenia tych zmian, moga one mieć wpływ na stabilność finansową aptek otwartych: zwiększenie liczby pacjentów na początku pandemii, która doprowadziła do przeciążenia pracą personelu i zmniejszenie liczby pacjentów po szczycie epidemii $(6,7)$.

\section{CEL PRACY}

Celem niniejszego badania było zebranie opinii pracowników i właścicieli aptek na temat funkcjonowania aptek otwartych $\mathrm{w}$ okresie wybuchu pandemii COVID-19.

\section{MATERIAŁY I METODY}

\section{Projekt badania i uczestnicy}

Badanie ma charakter przekrojowy i zostało przeprowadzone w Polsce za pomocą ankiety online. Dane zbierano od początku pandemii poprzez szczyt aż do momentu, w którym liczba aktywnych przypadków znacznie spadła (od 27 marca do 6 maja). Było to badanie pilotażowe skierowane do pracowników aptek (farmaceutów, techników farmaceutycznych, stażystów) oraz właścicieli, wśród których były osoby bez kwalifikacji do wykonywania zawodu farmaceuty. Badanie zostało zgłoszone do Komisji Etycznej z prośbą o zgodę, jednakże nie jest ona wymagana dla tego typu badania. Respondenci zostali poinformowani o celu badania w krótkim oświadczeniu przedstawionym na początku ankiety oraz zapewniono ich o pełnej anonimowości. Uznano, że respondenci, którzy wypełnili ankietę, wyrazili świadomą zgodę na udział $\mathrm{w}$ badaniu (8). Ankietę rozpowszechniano z wykorzystaniem mediów społecznościowych (Facebook) oraz stron internetowych dedykowanych personelowi aptek. Uczestnicy mieli możliwość konsultowania wszystkich uwag z członkami zespołu badawczego przez cały czas trwania badania.

\section{Opracowanie ankiety}

Ankieta została opracowana przez zespół badawczy po dokonaniu obszernej analizy literatury, ze szczególnym uwzględnieniem niedawno opublikowanych artykułów na temat pandemii. (9) Wolontariusze, nauczyciele akademiccy $z$ doświadczeniem $w$ dziedzinie farmacji społecznej oraz farmaceuci z wieloletnią praktyką zawodową w aptece otwartej ocenili ankietę pod kątem trafności fasadowej i treściowej. Czytel- 
sociodemographic and professional data, including the type of community pharmacy where respondents worked on a daily basis. The second part aimed to collect information regarding how the outbreak of the pandemic affected the workflow in community pharmacies in terms of the number of patients visiting the pharmacy, the number of pharmaceutical prescriptions issued by pharmacists, etc. The third part collected information about the security measures implemented in community pharmacies as a result of the pandemic, both as independent actions and actions recommended at the national level by governmental bodies.

\section{Statistical analysis}

The data were analyzed by an external consultant experienced in data analysis for scientific projects. The statistical package StatSoft. Inc. (2014) STATISTICA was used. The quantitative variables were characterized by the arithmetic mean, standard deviation, median, minimum and maximum values (range), and 95\% confidence interval (CI). The Shapiro-Wilk test was used to test the normal distribution of data. Different statistical tests were used to detect statistically significant differences between groups: the Student-ttest, Mann-Whitney U test, ANOVA F-test, KruskalWallis test, and Wilcoxon signed-rank test. If necessary, post hoc statistical analysis was performed. The ChiSquare test of independence was used for qualitative variables. The Pearson correlation coefficient or Spearman's rank correlation coefficient was calculated to determine the strength of the correlation between variables. The statistical significance level was 0.05 for all comparisons.

\section{RESULTS}

The study group included 456 respondents, mostly female $(82.7 \%)$. The most frequent age groups were 20-29-year-olds (29.2\%) and 30-39-year-olds (34.0\%). Regarding professional occupation, 184 respondents (40.4\%) were ordinary pharmacists and $114(25.0 \%)$ worked as pharmacy managers. Most respondents were associated with independent pharmacies (55.7\%), in cities with no more than 100,000 inhabitants $(38.8 \%)$. The data are summarized in Table I.

During the pandemic, the working hours remained unchanged in $76.3 \%$ of community pharmacies and were reduced in $21.5 \%$ (Fig. 1). Respondents declared that only $11.8 \%$ of healthcare centers situated near pharmacies were open as normal.

According to participants, an increased number of patients was observed in $76.5 \%$ of the pharmacies (Fig. 2). ność została oceniona na podstawie wskaźnika FOG (Gunning Fog Index), aby zapewnić, że ankieta będzie zrozumiała dla respondentów, biorąc pod uwagę ich poziom wykształcenia.

Ostateczna wersja ankiety składała się z trzech części. W pierwszej z nich gromadzono dane socjodemograficzne oraz dotyczące pracy zawodowej, w tym rodzaj apteki otwartej, w której respondenci pracowali na co dzień. Druga część miała na celu zebranie informacji na temat tego, w jaki sposób wybuch pandemii wpłynął na przepływ pracy w aptekach otwartych pod względem liczby pacjentów odwiedzających aptekę, liczby wystawionych przez farmaceutów recept farmaceutycznych itp. W trzeciej części zebrano informacje na temat środków bezpieczeństwa wdrożonych w aptekach otwartych w wyniku pandemii, zarówno $\mathrm{w}$ formie niezależnych działań, jak i działań zalecanych na szczeblu krajowym przez organy rządowe.

\section{Analiza statystyczna}

Dane zostały przeanalizowane przez zewnętrznego konsultanta zajmującego się analizą danych w projektach naukowych. Użyto oprogramowania STATISTICA (StatSoft. Inc., 2014). Zmienne ilościowe przedstawiono jako średnią arytmetyczną, odchylenie standardowe, medianę, wartość minimalną i maksymalną (zakres) oraz 95\% przedział ufności (CI). Normalność rozkładu sprawdzono testem Shapiro-Wilka. W celu wykrycia statystycznie istotnych różnic pomiędzy grupami zastosowano różne testy statystyczne: test tStudenta, test U Manna-Whitneya, test F - ANOVA, test Kruskala-Wallisa oraz test Wilcoxona dla par obserwacji. W razie konieczności przeprowadzano statystyczną analizę post hoc. Dla zmiennych jakościowych zastosowano test niezależności chi-kwadrat. W celu określenia siły związku między zmiennymi obliczono wartość współczynnika korelacji Pearsona lub współczynnika korelacji rang Spearmana. Dla wszystkich porównań przyjęto poziom istotności $\mathrm{p}<0,05$.

\section{WYNIKI}

Grupa badana obejmowała 456 respondentów, z których większość stanowiły kobiety $(82,7 \%)$. Przeważały osoby w dwóch kategoriach wieku: 20-29 lat $(29,2 \%)$ oraz $30-39$ lat $(34,0 \%)$. Biorąc pod uwage stanowisko pracy, 184 respondentów $(40,4 \%)$ było zatrudnionych na stanowisku farmaceuty, a 114 (25,0\%) pełniło funkcję kierownika apteki. Większość respondentów pracowała w aptekach prywatnych $(55,7 \%)$, w miastach do 100000 mieszkańców $(38,8 \%)$. Dane zestawiono w tabeli I.

$\mathrm{W}$ okresie pandemii nie zmieniono godzin pracy w $76,3 \%$ aptek otwartych, a w $21,5 \%$ zostały one skrócone (Ryc. 1). Zgodnie z odpowiedziami respondentów tylko $11,8 \%$ placówek medycznych zlokalizo- 
Table I. Characteristics of the study group

Tabela I. Charakterystyka grupy badanej

\begin{tabular}{|c|c|c|}
\hline & & $\begin{array}{c}\text { Study group / Grupa badana } \\
(\mathrm{n}=456)\end{array}$ \\
\hline \multirow{2}{*}{ Gender / Pleć } & Female/ Kobieta & $377(82.7 \%)$ \\
\hline & Male/ Mężczyzna & $79(17.3 \%)$ \\
\hline \multirow{7}{*}{$\begin{array}{l}\text { Professional occupation/ } \\
\text { Stanowisko pracy }\end{array}$} & Pharmacy manager / Kierownik apteki & $114(25.0 \%)$ \\
\hline & Pharmacist / Farmaceuta & $184(40.4 \%)$ \\
\hline & $\begin{array}{l}\text { Pharmacy owner with pharmaceutical education / } \\
\text { Właściciel apteki z wykształceniem farmaceutycznym }\end{array}$ & $85(18.6 \%)$ \\
\hline & Pharmacy technician / Technik farmaceutyczny & $56(12.2 \%)$ \\
\hline & $\begin{array}{l}\text { Pre-registration pharmacist / } \\
\text { Student farmacji w trakcie stażu }\end{array}$ & $5(1.1 \%)$ \\
\hline & $\begin{array}{l}\text { Pre-registration pharmacy technician / } \\
\text { Technik farmaceutyczny w trakcie stażu }\end{array}$ & $8(1.8 \%)$ \\
\hline & $\begin{array}{l}\text { Pharmacy owner without pharmaceutical education / } \\
\text { Właściciel apteki bez wykształcenia } \\
\text { farmaceutycznego }\end{array}$ & $4(0.9 \%)$ \\
\hline \multirow{5}{*}{ Age (years)/ Wiek (lata) } & $20-29$ & $133(29.2 \%)$ \\
\hline & $30-39$ & $155(34.0 \%)$ \\
\hline & $40-49$ & $104(22.8 \%)$ \\
\hline & $50-59$ & $40(8.8 \%)$ \\
\hline & 60 and over / i powyżej & $24(5.2 \%)$ \\
\hline \multirow{3}{*}{$\begin{array}{l}\text { Type of pharmacy / } \\
\text { Rodzaj apteki }\end{array}$} & Chain pharmacy / Apteka sieciowa & $199(43.6 \%)$ \\
\hline & Independent pharmacy / Apteka prywatna & $254(55.7 \%)$ \\
\hline & Limited program pharmacy / Punkt apteczny & $3(0.7 \%)$ \\
\hline \multirow{4}{*}{$\begin{array}{l}\text { Pharmacy location / } \\
\text { Lokalizacja apteki }\end{array}$} & Rural area / Obszar wiejski & $43(9.5 \%)$ \\
\hline & $\begin{array}{l}\text { A city of up to } 100,000 \text { inhabitants/ } \\
\text { Miasto do } 100000 \text { mieszkańców }\end{array}$ & $177(38.8 \%)$ \\
\hline & $\begin{array}{l}\text { A city between } 100,000 \text { and } 500,000 \text { inhabitants / } \\
\text { Miasto od } 100000 \text { do } 500000 \text { mieszkańców }\end{array}$ & $99(21.7 \%)$ \\
\hline & $\begin{array}{l}\text { A city of more than } 500,000 \text { inhabitants / } \\
\text { Miasto powyżej } 500000 \text { mieszkańców }\end{array}$ & $137(30.0 \%)$ \\
\hline
\end{tabular}

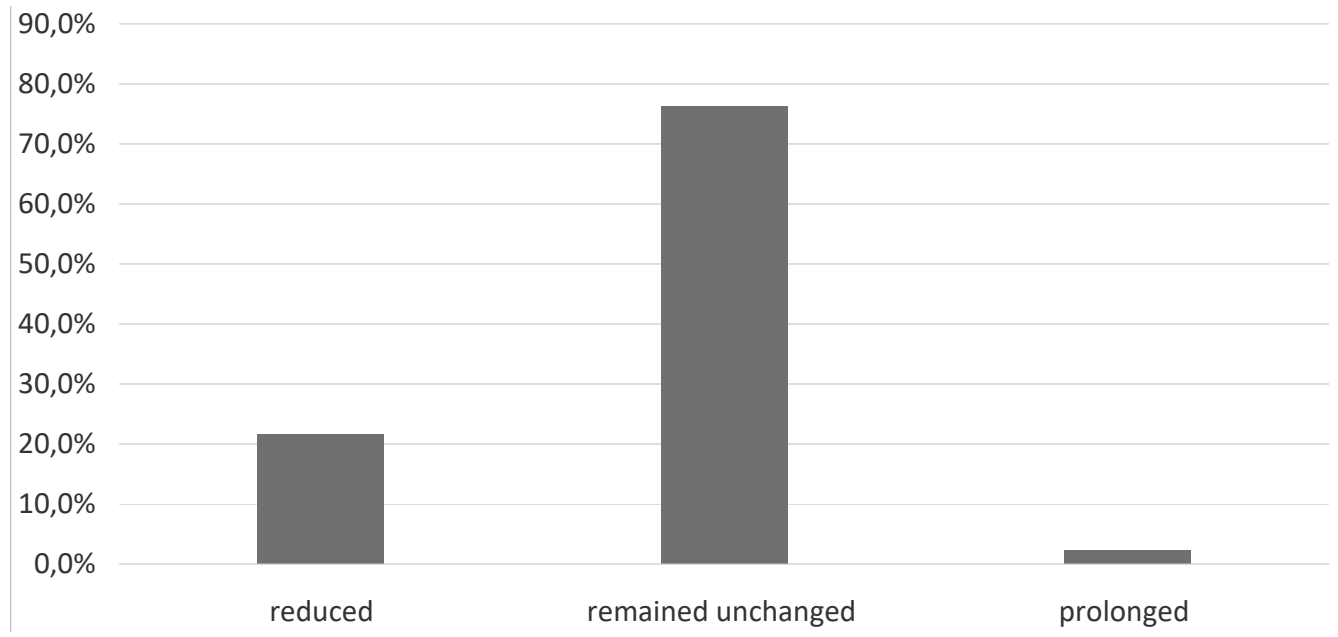

Fig. 1. Working hours for community pharmacies

Ryc. 1. Godziny pracy w aptekach otwartych 


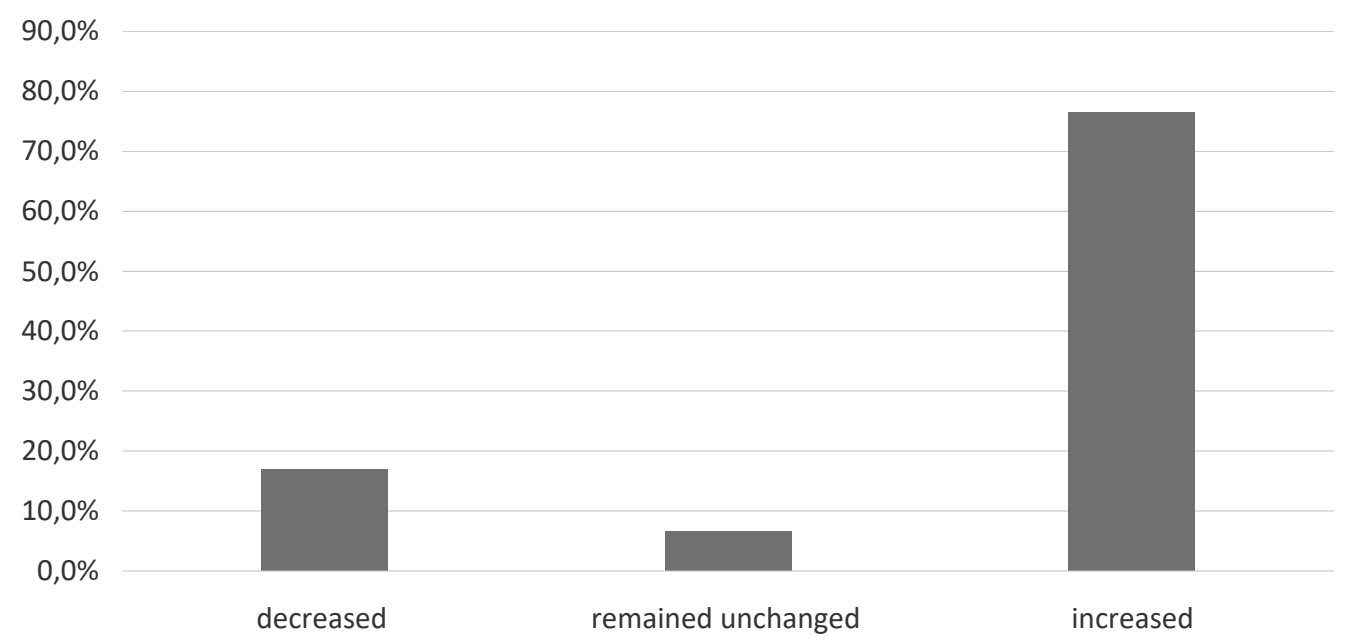

Fig. 2. The number of patients visiting community pharmacies.

Ryc. 2. Liczba pacjentów odwiedzających apteki otwarte.

Most (56.5\%) pharmacists declared that the number of pharmaceutical prescriptions issued during the pandemic was higher than before the outbreak. According to $94.5 \%$ of respondents, public authorities provided free safety measures during the pandemic, and $60.7 \%$ of participants reported that their community pharmacy was properly prepared for the pandemic by the owner. The data are summarized in Table II. wanych w pobliżu aptek funkcjonowało $\mathrm{w}$ godzinach sprzed pandemii.

Według odpowiedzi uczestników badania wzrost liczby pacjentów zaobserwowano w 76,5\% aptek (Ryc. 2).

Większość (56,5\%) farmaceutów zadeklarowało, że liczba recept farmaceutycznych wystawionych podczas pandemii była wyższa niż przed wybuchem epidemii. 94,5\% respondentów odpowiedziało, że organy publiczne zapewniły bezpłatne środki ochrony podczas pandemii, a $60,7 \%$ uczestników podało, że ich apteka otwarta została odpowiednio przystosowana przez właściciela do pracy w warunkach pandemii. Dane zestawiono w tabeli II.

Table II Characteristics of community pharmacies and pharmaceutical counseling

Tabela II Charakterystyka aptek otwartych i poradnictwo farmaceutyczne

\begin{tabular}{|l|c|}
\hline & $\begin{array}{c}\text { "yes" answers / } \\
\text { Odpowiedzi “tak" }\end{array}$ \\
\hline $\begin{array}{l}\text { Were the healthcare centers near your pharmacies open as normal, according to their } \\
\text { opening hours? / } \\
\text { Czy placówki medyczne w pobliżu Pana/Pani apteki były otwarte jak zwykle, zgodnie } \\
\text { z godzinami otwarcia? }\end{array}$ & 54 (11.8\%) \\
\hline $\begin{array}{l}\text { Did you observe an increased number of patients in your pharmacy due to the closing of } \\
\text { nearby healthcare centers? / } \\
\text { Czy zaobserwowal/-a Pan/Pani wzrost liczby pacjentów w Pana/Pani aptece } \\
\text { spowodowany zamknięciem pobliskich placówek medycznych? }\end{array}$ & 349 (76.5\%) \\
\hline $\begin{array}{l}\text { Was the number of pharmaceutical prescriptions issued by pharmacists higher during } \\
\text { the pandemic than before the outbreak? / } \\
\text { Czy liczba wystawionych recept farmaceutycznych byla wyższa w czasie pandemii } \\
\text { w porównaniu do liczby sprzed pandemii? }\end{array}$ & $\begin{array}{c}175 \text { (56.5\%) } \\
\text { wyłącznie } \\
\text { Do you think the owner properly prepared the community pharmacy for the pandemic? / } \\
\text { Czy uważa Pan/Pani, że właściciel apteki odpowiednio przystosowal aptekę otwartą do } \\
\text { pracy w warunkach pandemii? }\end{array}$ \\
\hline $\begin{array}{l}\text { Should public authorities provide free protective safety measures during the epidemic? / } \\
\text { Czy władze publiczne powinny bezpłatnie zapewniać środki ochrony podczas epidemii? }\end{array}$ & 318 (69.7\%) \\
\hline
\end{tabular}


The number of filled prescriptions increased during the pandemic, according to most participants (63.4\%). Respondents provided patients with advice on different topics, including the common cold (81.6\%), sore throat (77.0\%), and ache-related complaints (68.6\%). Most participants (64.5\%) declared that they informed patients about COVID-19. The full list of topics is described in Table III.

The most common reasons patients visited community pharmacies during the pandemic were to purchase over-the-counter products for the treatment of COVID-19-related symptoms (90.6\%), to seek advice on the treatment of various ailments (78.3\%), to ask for recommendations following the shutdown of healthcare centers $(57.0 \%)$, and to get information on medicine use (56.1\%) (Tab. IV).
Według większości uczestników $(63,4 \%)$ liczba zrealizowanych recept wzrosła w okresie pandemii. Respondenci udzielali pacjentom porad w różnych dolegliwościach, m.in. na temat przeziębienia $(81,6 \%)$, bólu gardła $(77,0 \%)$ i innych dolegliwości bólowych $(68,6 \%)$. Większość uczestników badania $(64,5 \%)$ zadeklarowało, że informowali pacjentów o COVID-19. Pełna lista tematów została przedstawiona w tabeli III.

Najczęstszymi powodami, dla których pacjenci odwiedzali apteki otwarte w czasie pandemii były: zakup leków wydawanych bez recepty (OTC) do leczenia objawów związanych z COVID-19 (90,6\%), chęć zasięgnięcia porady $\mathrm{w}$ zakresie leczenia różnych dolegliwości $(78,3 \%)$, otrzymania zaleceń po zamknięciu placówek medycznych $(57,0 \%)$ oraz uzyskania informacji na temat stosowania leków $(56,1 \%)$ (Tab. IV).

Table III Pharmaceutical advice given to patients - the range of topics

Tabela III Porady farmaceutyczne skierowane do pacjentów - zakres tematów

\begin{tabular}{|c|c|}
\hline & $\begin{array}{l}\text { Study group / Grupa badana } \\
\qquad(n=456)\end{array}$ \\
\hline Common cold / Przeziębienie & $372(81.6 \%)$ \\
\hline Sore throat / Ból gardła & $351(77.0 \%)$ \\
\hline Ache / Ból & $313(68.6 \%)$ \\
\hline COVID-19-related information / Informacje dotyczące COVID-19 & $294(64.5 \%)$ \\
\hline Inflammation of bladder (cystitis) / Zapalenie pęcherza moczowego & $245(53.7 \%)$ \\
\hline Insomnia / Bezsenność & $240(52.6 \%)$ \\
\hline Constipation / Zaparcia & $236(51.8 \%)$ \\
\hline Dry skin / Suchość skóry & $234(51.3 \%)$ \\
\hline Hemorrhoids / Hemoroidy & $209(45.8 \%)$ \\
\hline Herpes labialis / Opryszczka wargowa & $208(45.6 \%)$ \\
\hline Proper supplementation / Odpowienia suplementacja & $199(43.6 \%)$ \\
\hline Gastroenteritis / Zapalenie żołądka i jelit & $196(43.0 \%)$ \\
\hline Allergic rhinitis / Alergiczny nieżyt nosa & $194(42.5 \%)$ \\
\hline Conjunctivitis / Zapalenie spojówek & $184(40.4 \%)$ \\
\hline Pain in the lumbosacral junction / Ból w odcinku lędźwiowo-krzyżowym & $173(37.9 \%)$ \\
\hline Excess ear wax / Nadmiar woskowiny w uchu & $133(29.2 \%)$ \\
\hline Pediculosis (head lice) / Wszawica & $131(28.7 \%)$ \\
\hline Vaginal yeast infection / Grzybica pochwy & $121(26.5 \%)$ \\
\hline Smoking cessation / Rzucenie palenia & $112(24.6 \%)$ \\
\hline Mouth ulcers / Owrzodzenia jamy ustnej & $107(23.5 \%)$ \\
\hline Baby colic / Kolka niemowlęca & $103(22.6 \%)$ \\
\hline Acne / Trądzik & $103(22.6 \%)$ \\
\hline Dyspepsia / Niestrawność & $86(18.9 \%)$ \\
\hline Menstrual pain / Bóle menstruacyjne & $80(17.5 \%)$ \\
\hline Chickenpox / Ospa wietrzna & $75(16.4 \%)$ \\
\hline Candidiasis of the skin / Kandydoza skóry & $69(15.1 \%)$ \\
\hline Various ailments / Różne dolegliwości & $42(9.2 \%)$ \\
\hline
\end{tabular}


Table IV The most common reasons for a patient's visit to the community pharmacy during the pandemic, according to the respondents

Tabela IV Najczęstsze powody wizyty pacjenta w aptece otwartej w okresie pandemii według respondentów

\begin{tabular}{|l|c|}
\hline & $\begin{array}{c}\text { Study group / Grupa badana } \\
\text { (n=456) }\end{array}$ \\
\hline $\begin{array}{l}\text { Purchasing over-the-counter medicine dedicated to the treatment of COVID- } \\
\text { 19-related symptoms / } \\
\text { Zakup leków wydawanych bez recepty przeznaczonych do leczenia objawów } \\
\text { związanych z COVID-19 }\end{array}$ & $413(90.6 \%)$ \\
\hline $\begin{array}{l}\text { Seeking advice on the treatment of various ailments / } \\
\text { Otrzymanie porad w zakresie leczenia różnych dolegliwości }\end{array}$ & $357(78.3 \%)$ \\
\hline $\begin{array}{l}\text { Seeking recommendations due to closed healthcare centers/ } \\
\text { Otrzymanie zaleceń ze względu na zamknięte placówki medyczne }\end{array}$ & $260(57.0 \%)$ \\
\hline $\begin{array}{l}\text { Obtaining information on proper medicine use/ } \\
\text { Uzyskanie informacji na temat prawidłowego stosowania leków }\end{array}$ & $256(56.1 \%)$ \\
\hline $\begin{array}{l}\text { Refilling prescriptions for chronic diseases/ } \\
\text { Realizacja recepty na leki stosowane przewlekle }\end{array}$ & $248(54.4 \%)$ \\
\hline $\begin{array}{l}\text { Purchasing over-the-counter medicine intended for treatments other than for } \\
\text { COVID-19-related symptoms, dietary supplements, cosmetics/ } \\
\text { Zakup leków wydawanych bez recepty przeznaczonych do leczenia objawów } \\
\text { niezwiązanych z COVID-19, suplementów diety, kosmetyków }\end{array}$ & $221(48.5 \%)$ \\
\hline $\begin{array}{l}\text { Reporting adverse actions / } \\
\text { Zgłoszenie działań niepożądanych }\end{array}$ & $\begin{array}{l}\text { Obtaining information on the pandemic / } \\
\text { Uzyskanie informacji na temat pandemii }\end{array}$ \\
\hline
\end{tabular}

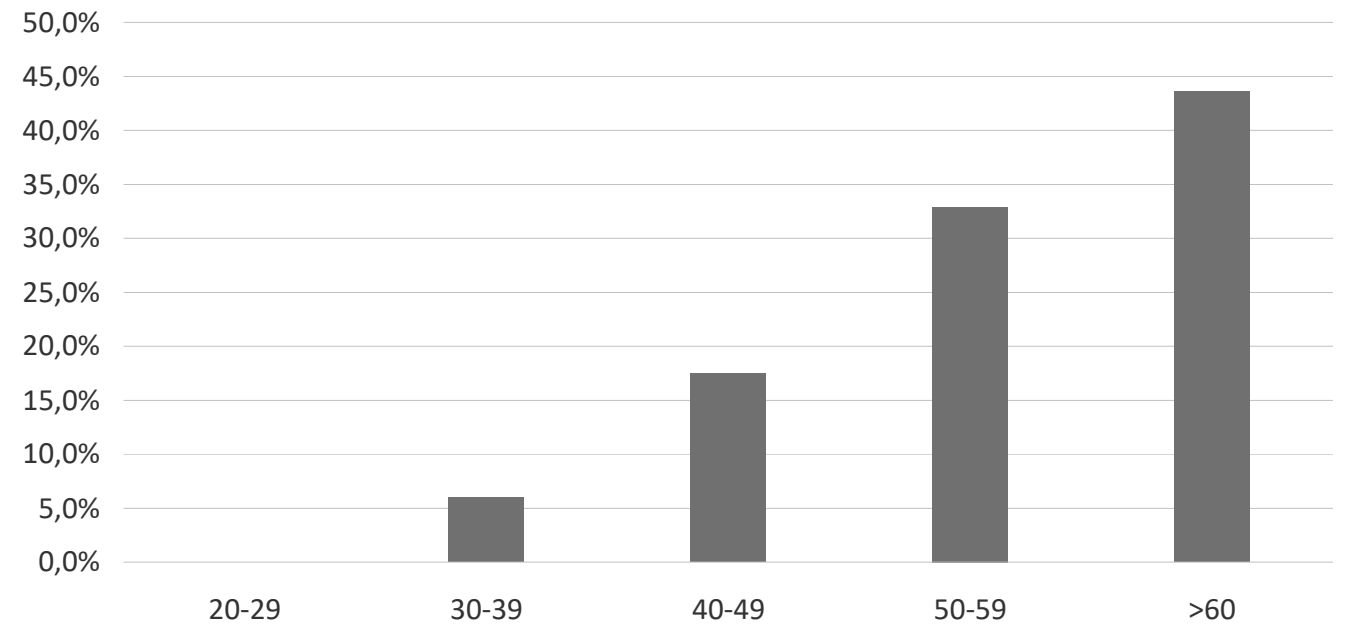

Ryc. 3. Wiek pacjentów odwiedzających apteki otwarte w czasie pandemii wg opinii respondentów.

Fig. 3. Age of the patients who visited community pharmacies during the pandemic, according to the respondents' opinion.

The patients who most often visited community pharmacies during the pandemic were 60 years old and older (43.6\%), 50-59 years old (32.9\%) and 40-49 years old (17.5\%) (Fig. 3).

The most frequently used safety measures in community pharmacies included a poster about safety regulations to be followed during the pandemic (97.1\%), handwashing in accordance with recommended guidelines $(96.3 \%)$, and the use of protective gloves by the pharmacy staff (89.9\%). The security measures
Pacjenci, którzy w czasie pandemii najczęściej odwiedzali apteki otwarte byli w wieku 60 lat lub więcej $(43,6 \%), 50-59$ lat $(32,9 \%)$ oraz $40-49$ lat $(17,5 \%)$ (Ryc. 3).

Do najczęściej stosowanych w aptekach otwartych środków bezpieczeństwa należały: plakaty dotyczące przepisów bezpieczeństwa, których należy przestrzegać w czasie pandemii $(97,1 \%)$, mycie rąk zgodnie z zalecanymi wytycznymi $(96,3 \%)$ oraz używanie rękawiczek ochronnych przez personel apteki (89,9\%). 
were in line with the recommendations suggested by the National Pharmaceutical Chamber and the Main Sanitary Inspectorate, according to $91.2 \%$ of participants (Tab. V).
Według 91,2\% uczestników badania wdrożone środki bezpieczeństwa były zgodne z zaleceniami Naczelnej Izby Aptekarskiej i Głównego Inspektoratu Sanitarnego (Tab. V).

Table V Safety measures introduced into the community pharmacy due to the pandemic

Tabela V Środki bezpieczeństwa wprowadzone do apteki otwartej w związku z pandemią

\begin{tabular}{|c|c|}
\hline & $\begin{array}{c}\text { Study group / Grupa badana } \\
(\mathrm{n}=\mathbf{4 5 6})\end{array}$ \\
\hline $\begin{array}{l}\text { A poster about safety regulations during the coronavirus pandemic / } \\
\text { Plakat dotyczący przepisów bezpieczeństwa podczas pandemii koronawirusa }\end{array}$ & $443(97.1 \%)$ \\
\hline $\begin{array}{l}\text { Hand washing in accordance with recommendations / } \\
\text { Mycie rąk zgodnie z zaleceniami }\end{array}$ & $439(96.3 \%)$ \\
\hline $\begin{array}{l}\text { Implementation of security measures in accordance with the standards } \\
\text { suggested by the National Pharmaceutical Chamber and Main Sanitary } \\
\text { Inspectorate / } \\
\text { Wdrożenie środków bezpieczeństwa zgodnie z zaleceniami Naczelnej Izby } \\
\text { Aptekarskiej i Glównego Inspektoratu Sanitarnego }\end{array}$ & $416(91.2 \%)$ \\
\hline $\begin{array}{l}\text { Use of protective gloves by the staff / } \\
\text { Używanie rękawiczek ochronnych przez personel }\end{array}$ & $410(89.6 \%)$ \\
\hline $\begin{array}{l}\text { Regular disinfection of surfaces exposed to the virus / } \\
\text { Regularna dezynfekcja powierzchni narażonych na skażenie wirusem }\end{array}$ & $383(84.0 \%)$ \\
\hline $\begin{array}{l}\text { Implementation of safe distancing (over } 1 \text { meter) measures / } \\
\text { Zapewnienie zachowania bezpiecznej odleglości (powyżej } 1 \text { metra) }\end{array}$ & $381(83.6 \%)$ \\
\hline $\begin{array}{l}\text { Educational material on the coronavirus pandemic / } \\
\text { Materiały edukacyjne na temat pandemii koronawirusa }\end{array}$ & $376(82.5 \%)$ \\
\hline $\begin{array}{l}\text { Use of a designated buffer zone for patients waiting in line / } \\
\text { Wydzielenie strefy buforowej dla pacjentów czekających w kolejce }\end{array}$ & $350(76.8 \%)$ \\
\hline Regular aereation of pharmacy counters / Regularne wietrzenie apteki & $342(75.0 \%)$ \\
\hline $\begin{array}{l}\text { Installation of protective barriers at the point of drug dispensing / } \\
\text { Zainstalowanie oslon ochronnych w miejscu wydawania leków }\end{array}$ & $308(67.5 \%)$ \\
\hline \multicolumn{2}{|l|}{$\begin{array}{l}\text { Where are the poster and educational materials from the pharmacy from? / } \\
\text { Skąd pochodzą plakaty i materialy edukacyjne? }\end{array}$} \\
\hline Ministry of Health / Ministerstwo Zdrowia & $250(54.8 \%)$ \\
\hline National Pharmaceutical Chamber / Naczelna Izba Aptekarska & $191(41.9 \%)$ \\
\hline Main Sanitary Inspectorate / Hurtownia farmaceutyczna & $135(29.6 \%)$ \\
\hline Pharmaceutical wholesale / Gtówny Inspektorat Sanitarny & $143(31.4 \%)$ \\
\hline $\begin{array}{l}\text { Use of surgical (protective) masks by the staff / } \\
\text { Używanie masek chirurgicznych (ochronnych) przez personel }\end{array}$ & $214(46.9 \%)$ \\
\hline $\begin{array}{l}\text { Drug dispensing through the small window on the door normally used for } \\
\text { night service / } \\
\text { Wydawanie leków przez małe okienko w drzwiach, zwykle używane w trakcie } \\
\text { dyżurów nocnych }\end{array}$ & $61(21.6 \%)$ \\
\hline $\begin{array}{l}\text { Regular disinfection with ozone / } \\
\text { Regularna dezynfekcja ozonem }\end{array}$ & $29(6.4 \%)$ \\
\hline $\begin{array}{l}\text { Use of protective helmet - face shield mask / } \\
\text { Stosowanie przylbic }\end{array}$ & $23(5.0 \%)$ \\
\hline
\end{tabular}

Male respondents reported that the community pharmacy was properly prepared for the pandemic by the owner significantly more often than female participants $(\mathrm{p}=0.0013)$. A greater number of patients was observed in independent pharmacies compared to
Spośród respondentów znacznie więcej mężczyzn niż kobiet stwierdziło, że apteka otwarta była odpowiednio przystosowana przez właściciela do pracy $\mathrm{w}$ warunkach pandemii $(\mathrm{p}=0,0013)$. Większą liczbę pacjentów obserwowano $\mathrm{w}$ aptekach prywat- 
chain pharmacies $(\mathrm{p}=0.0013)$. Moreover, the number of prescriptions issued by pharmacists in independent pharmacies during the pandemic was significantly higher than the number of prescriptions issued in chain pharmacies $(p=0.0105)$. Respondents from chain pharmacies indicated significantly more often that educational materials on pandemic-related issues were placed in the pharmacy during the pandemic $(\mathrm{p}=$ 0.0057). Respondents from independent pharmacies more frequently indicated that the community pharmacy was properly prepared for the pandemic by the owner $(\mathrm{p}=0.0001)$. Data are summarized in Table VI. nych w porównaniu do aptek sieciowych $(\mathrm{p}=0,0013)$. $\mathrm{W}$ aptekach prywatnych wystawiono znacznie więcej recept farmaceutycznych niż w aptekach sieciowych $(p=0,0105)$. Respondenci pracujący $w$ aptekach sieciowych znacznie częściej deklarowali, że w czasie pandemii w aptece umieszczane były materiały edukacyjne zawierające informacje na temat pandemii $(p=0,0057)$. Respondenci pracujący w aptekach prywatnych częściej deklarowali, że apteka otwarta została odpowiednio przystosowana przez właściciela do pracy w warunkach pandemii $(\mathrm{p}=0,0001)$. Dane zestawiono w tabeli VI.

Table VI Comparisons between sub-populations in selected questions: women vs. men, pharmacy staff working in chain pharmacy vs. independent pharmacy

Tabela VI Porównania pomiędzy subpopulacjami w wybranych pytaniach: kobiety vs mężczyźni, personel pracujący $\mathrm{w}$ aptekach sieciowych w porównaniu z personelem $\mathrm{z}$ aptek prywatnych

\begin{tabular}{|c|c|c|c|}
\hline & $\begin{array}{l}\begin{array}{l}\text { Women / } \\
\text { Kobiety } \\
(n=377)\end{array} \\
\end{array}$ & $\begin{array}{c}\text { Men / } \\
\text { Mężczyźni } \\
(\mathbf{n}=79) \\
\end{array}$ & $\begin{array}{c}P \text {-value / } \\
\text { Wartość p }\end{array}$ \\
\hline \multirow{2}{*}{$\begin{array}{l}\text { Do you think the community pharmacy was properly prepared for } \\
\text { the pandemic by the owner? / } \\
\text { Czy uważa Pan/Pani, że wlaściciel apteki odpowiednio } \\
\text { przystosowal aptekę otwartą do pracy w warunkach pandemii? }\end{array}$} & $251(66.6 \%)$ & $67(84.8 \%)$ & 0.0013 \\
\hline & $\begin{array}{l}\text { Chain } \\
\text { pharmacy / } \\
\text { Apteka } \\
\text { sieciowa } \\
(\mathbf{n}=199)\end{array}$ & $\begin{array}{c}\text { Independent } \\
\text { pharmacy } \\
\text { (non-chain } \\
\text { pharmacy) / } \\
\text { Apteka } \\
\text { prywatna } \\
\text { (niesieciowa) } \\
(\mathbf{n}=\mathbf{2 5 4}) \\
\end{array}$ & $P$-value \\
\hline $\begin{array}{l}\text { Did you observe an increased number of patients in your } \\
\text { pharmacy due to the closing of nearby healthcare centers? / } \\
\text { Czy zaobserwowat/-a Pan/Pani wzrost liczby pacjentów w Pana/ } \\
\text { Pani aptece spowodowany zamknięciem pobliskich placówek } \\
\text { medycznych? }\end{array}$ & $138(69.3 \%)$ & $209(82.3 \%)$ & 0.0013 \\
\hline $\begin{array}{l}\text { Was the number of pharmaceutical prescriptions issued by } \\
\text { pharmacists higher during the pandemic than before the } \\
\text { outbreak? / } \\
\text { Czy liczba wystawionych recept farmaceutycznych była wyższa } \\
\text { w czasie pandemii w porównaniu do liczby sprzed pandemii? }\end{array}$ & $56(47.5 \%)$ & $119(62.3 \%)$ & 0.0105 \\
\hline $\begin{array}{l}\text { Is educational material on the coronavirus pandemic present in } \\
\text { the pharmacy? / } \\
\text { Czy w aptece są dostępne materiały dotyczące pandemii } \\
\text { koronawirusa? }\end{array}$ & $175(87.9 \%)$ & $198(78.0 \%)$ & 0.0057 \\
\hline $\begin{array}{l}\text { Do you think the community pharmacy was properly prepared for } \\
\text { the pandemic by the owner? / } \\
\text { Czy uważa Pan/Pani, że wlaściciel apteki odpowiednio } \\
\text { przystosowal aptekę otwartą do pracy w warunkach pandemii? }\end{array}$ & $116(58.3 \%)$ & $200(78.7 \%)$ & 0.0001 \\
\hline
\end{tabular}

\section{DISCUSSION}

This study revealed the significant effort made by pharmacists and their teams to fulfill their role during the SARS-CoV-2 pandemic. An increased number

\section{DYSKUSJA}

Badanie to wykazało, że farmaceuci wraz z całym zatrudnionym w aptekach zespołem wkładają znaczny wysiłek, aby wypełniać swoje obowiązki w okresie 
of patients has resulted in an increased number of pharmaceutical prescriptions, leading to a burden for the community pharmacy. Patients visited pharmacies mostly to purchase over-the-counter drugs to treat COVID-19-related symptoms (e.g. cough or fever) and to seek medical information on various topics following the shutdown of healthcare centers. Most Polish medical centers, including medical consultations with general practitioners, have been working on a limited basis during the pandemic. However, some physicians offer only telephone consultations, and there are patients that prefer face-to-face contact in the pharmacy. Respondents also declared that various safety measures were introduced into community pharmacies to protect pharmacy staff and patients from contamination. Among other measures, hands were washed in accordance with recommendations, protective gloves were used by the pharmacy staff, and surfaces exposed to the virus were regularly disinfected. Posters about safety regulations were available in almost all community pharmacies; however, they were distributed by the national authorities and were required by the law. Keeping a buffer zone and safe distance were also enforced routinely. Nevertheless, only $70 \%$ of respondents stated that the community pharmacy was properly prepared for the pandemic by the owner. The respondents also agreed that public authorities should provide free protective safety measures during the pandemic in pharmacy .

Although the coronavirus pandemic remains a relatively new topic, numerous studies have been published regarding the role of pharmacists and of pharmaceutical care in the face of a healthcare system that is struggling with an increased number of patients. In China, the first country hit by the pandemic, pharmacists emphasized that they should ensure uninterrupted access to medications and preventive disinfectants (10). Patient education should not only be limited to chronic diseases, but COVID-19-related issues should also be in the spotlight. Among other issues, pharmacy staff should provide information on how to minimize the risk of contamination (7). Pharmacists should also understand that some patients should be immediately referred to hospital settings after an initial interview in the pharmacy (11). Pharmacists can play a key role in reducing patient misinformation $(8,12-13)$ Pharmacy staff should understand that patients can perceive the risks related to the control of the pandemic differently. Patientcentered education can build awareness among patients, who should not underestimate the potential consequences of COVID-19 but also not be paralyzed by fear $(5,14)$. This is partially consistent with this study's findings regarding one of the primary reasons patients visited community pharmacies, which was to pandemii wywołanej SARS-CoV-2. Większa liczba pacjentów skutkowała większą ilością wystawionych recept farmaceutycznych, co doprowadziło do obciążenia aptek otwartych..? Pacjenci odwiedzali apteki głównie w celu zakupu preparatów OTC do leczenia objawów występujących w COVID-19 (np. kaszel lub gorączka) oraz uzyskania informacji na różne tematy zdrowotne po zamknięciu placówek medycznych. Większość polskich centrów medycznych, w tym podstawowa opieka zdrowotna, funkcjonuje w ograniczonym zakresie w okresie pandemii. Niektórzy lekarze oferują tylko konsultacje telefoniczne, a część pacjentów woli kontakt osobisty, który jest możliwy w aptece. Respondenci zadeklarowali również, że w aptekach otwartych wdrożono różne środki bezpieczeństwa w celu ochrony personelu i pacjentów przed zakażeniem, m.in. mycie rąk zgodnie z zaleceniami, stosowanie przez pracowników aptek rękawiczek ochronnych oraz regularna dezynfekcja powierzchni narażonych na skażenie wirusem. Plakaty dotyczące przepisów bezpieczeństwa były dostępne w prawie wszystkich aptekach otwartych, jednak były one dystrybuowane przez władze krajowe, a ich umieszczenie w aptece wymagane przez prawo. Rutynowo nakazywano również zachowanie strefy buforowej i bezpiecznej odległości. Tym niemniej tylko $70 \%$ respondentów stwierdziło, że apteka otwarta została odpowiednio przystosowana przez właściciela do pracy w warunkach pandemii. Respondenci uważali również, że władze publiczne powinny zapewnić bezpłatne środki ochronne podczas pandemii $\mathrm{w}$ aptece.

Pomimo tego, że pandemia koronawirusa jest stosunkowo nowym tematem, opublikowano liczne badania dotyczące roli farmaceutów i opieki farmaceutycznej w systemie opieki zdrowotnej, który zmaga się ze zwiększoną liczbą pacjentów. W Chinach, pierwszym kraju dotkniętym pandemią, farmaceuci podkreślali, że powinni zapewniać nieprzerwany dostęp do leków i środków odkażających (10). Edukacja pacjentów powinna nie tylko ograniczać się do tematów dotyczących chorób przewlekłych, ale także skupiać się na kwestiach związanych z COVID-19. Personel aptek powinien udzielać informacji, jak zmniejszyć ryzyko zakażenia (7). Ponadto farmaceuci powinni być świadomi, że niektórych pacjentów należy natychmiast kierować do szpitala po przeprowadzeniu wstępnej rozmowy w aptece otwartej (11). Farmaceuci mogą odgrywać kluczową rolę w ograniczaniu zjawiska dezinformacji pacjentów $(8,12-13)$. Personel aptek powinien rozumieć, że pacjenci w różny sposób postrzegają ryzyko związane $\mathrm{z}$ pandemią. Edukacja zorientowana na pacjenta może budować świadomość wśród pacjentów, którzy nie powinni lekceważyć potencjalnych skutków COVID-19, ale też nie mogą być sparaliżowani strachem $(5,14)$. Jest to częściowo zgod- 
refill prescriptions for chronic diseases; although only $54.4 \%$ of respondents reported this.

More advanced pharmaceutical services should be provided in such a way as to minimize the risk of contamination. After careful consideration of the risk and benefit ratio, some of these services could be postponed until the pandemic is under control. Pharmacy staff should consider introducing additional practice to effectively respond to current needs, such as monitoring the scientific literature and identifying cases in which drugs can be used off label to treat COVID-19 (15-16). Due to the limited number of advanced pharmaceutical services generally available in Polish community pharmacies, this area of investigation was not mentioned in the study. A medication review can be provided based on electronic prescriptions and e-medical records to minimize direct face-to-face communication (17). Just before the pandemic outbreak, e-prescription had been widely popularized in the Polish healthcare system, which significantly facilitated the management of the pandemic (18).

The main limitation of the present study is associated with the distribution of the questionnaire. The study was conducted via the Internet, and a significant number of respondents might have been excluded from the study, considering that not everyone may be willing to participate in online scientific investigations. Some people may not be willing to discuss sensitive topics in an online questionnaire. However, an online survey ensured safety during the pandemic and facilitated the collection of a significant amount of data from geographically dispersed respondents. Another limitation related to the online nature of this survey is that the study population was not balanced: for example, only four participants were pharmacy owners without formal pharmaceutical education. Moreover, whether the pharmacy owners with pharmaceutical education worked as pharmacists regularly is not known.

This study also has practical implications. $60.7 \%$ of respondents agreed that the pharmacy owners properly protected the community pharmacies from the risk associated with COVID-19. These results agree with those obtained by Hoti et al., who reported that over twothirds of participants agreed that their pharmacies were sufficiently prepared in terms of protective measures used by the staff (19). This poses a threat to public health, since a well-protected community pharmacy not only ensures safety for the staff but also minimizes the risk of contamination for visiting patients.

\section{CONCLUSIONS}

Pharmacy staff and owners are aware of the role of community pharmacies in the healthcare system ne $\mathrm{z}$ wynikami przedstawionego badania biorąc pod uwagę, że jednym z głównych powodów, dla którego pacjenci odwiedzali apteki otwarte było chęć zrealizowania recepty na stosowane przewlekle leki (chociaż tylko 54,4\% respondentów zaznaczyło tę odpowiedź).

Bardziej zaawansowane usługi farmaceutyczne powinny być świadczone w taki sposób, aby minimalizować ryzyko zakażenia. Po dokładnej analizie stosunku korzyści do ryzyka, można stwierdzić, że realizacja niektórych usług mogłaby zostać odroczona do czasu opanowania pandemii. W celu skutecznego reagowania na bieżące potrzeby pracownicy aptek powinni rozważyć wprowadzenie dodatkowych praktyk, takich jak śledzenie literatury naukowej i wyszukiwanie przypadków, w których można zastosować leki poza wskazaniami rejestracyjnymi w leczeniu COVID-19 (15-16). Ze względu na ograniczoną liczbę zaawansowanych usług farmaceutycznych ogólnie dostępnych w polskich aptekach otwartych nie uwzględniono tego obszaru badań w niniejszej pracy. Przeglądu lekowego można dokonać na podstawie elektronicznych recept i elektronicznej dokumentacji medycznej, aby ograniczyć ilość kontaktów w formie osobistej (17). Tuż przed wybuchem pandemii e-recepty zostały szeroko spopularyzowane w polskim systemie ochrony zdrowia, co znacznie pomogło w opanowywaniu pandemii (18).

Główne ograniczenie niniejszego badania wiąże się ze sposobem dystrybucji ankiety. Badanie zostało przeprowadzone za pośrednictwem Internetu, co mogło zniechęcić znaczną grupę odbiorców do wypełnienia ankiety, ponieważ nie wszyscy chętnie biorą udział w internetowych badaniach naukowych. Niektórzy ludzie nie chcą omawiać drażliwych tematów $\mathrm{w}$ ankiecie online. Badanie internetowe umożliwiło jednak zarówno zapewnienie bezpieczeństwa w trakcie pandemii, jak i zebranie znacznej ilości danych od respondentów z różnych regionów Polski. Innym ograniczeniem związanym $\mathrm{z}$ internetowym charakterem niniejszej ankiety jest to, że badana populacja nie była zrównoważona: przykładowo, tylko czterech uczestników badania było właścicielami aptek nie będąc magistrami farmacji. Ponadto nie wiadomo, czy właściciele aptek z wykształceniem farmaceutycznym pracowali regularnie jako farmaceuci.

Niniejsze badanie ma również znaczenie praktyczne. $60,7 \%$ respondentów przyznało, że właściciele aptek odpowiednio zabezpieczyli apteki otwarte przed ryzykiem związanym z COVID-19. Wyniki te są zgodne z wynikami otrzymanymi przez Hoti i wsp., którzy wykazali, że ponad dwie trzecie uczestników badania przyznało, że w aptekach otwartych, w których pracowali, wdrożono odpowiednie środki bezpieczeństwa (19). Stanowi to zagrożenie dla zdrowia publicznego, ponieważ dobrze zabezpieczona apteka otwarta nie tylko zapewnia bezpieczeństwo pracow- 
during the COVID-19 pandemic. Public authorities and government institutions should pay more attention to patient safety in community pharmacies. The risk associated with insufficiently protected community pharmacies should not be underestimated. Response to the SARS-CoV-2 pandemic should be evaluated and lessons should be learned so that the healthcare systems are ready when a new pandemic, or another global crisis, happens.

Funding: This research was funded by the Polish Pharmaceutical Group S.A, grant number PGF/2/2020.

\section{REFERENCES}

1. Al-Quteimat OM, Amer AM. SARS-CoV-2 outbreak: How can pharmacists help? Res Soc Adm Pharm 2021 Feb;17(2):480-482.

2. Elbeddini A, Yeats A. Pharmacist intervention amid the coronavirus disease 2019 (COVID-19) pandemic: from direct patient care to telemedicine. J Pharm Policy Pract 2020 May 27;13:23.

3. Nguy J, Hitchen SA, Hort AL, et al. The role of a Coronavirus disease 2019 pharmacist: an Australian perspective. Int J Clin Pharm 2020 Oct;42(5):1379-1384.

4. Dawoud D. Emerging from the other end: Key measures for a successful COVID-19 lockdown exit strategy and the potential contribution of pharmacists. Res Soc Adm Pharm 2021 Jan;17(1):1950-1953.

5. Kretchy IA, Asiedu-Danso M, Kretchy JP. Medication management and adherence during the COVID-19 pandemic: Perspectives and experiences from low-and middle-income countries. Res Soc Adm Pharm 2021 Jan;17(1):2023-2026.

6. Bukhari N, Rasheed H, Nayyer B. Pharmacists at the frontline beating the COVID-19 pandemic. J Pharm Policy Pract 2020;13,8.

7. Zheng S, Yang L, Zhou P Li. Recommendations and guidance for providing pharmaceutical care services during COVID-19 pandemic: A China perspective. Res Soc Adm Pharm 2021 Jan;17(1):1819-1824.

8. Basheti IA, Nassar R, Barakat M, et al. Pharmacists' readiness to deal with the coronavirus pandemic: Assessing awareness and perception of roles. Res Soc Adm Pharm 2021 Mar;17(3):514-522.

9. Cadogan CA, Hughes CM. On the frontline against COVID-19: Community pharmacists' contribution during a public health crisis. Res Soc Adm Pharm 2021 Jan;17(1):2032-2035.

10. Ying W, Qian Y, Kun Z. Drugs supply and pharmaceutical care management practices at a designated hospital during the COVID-19 epidemic. Res Soc Adm Pharm 2021 Jan;17(1):19781983. nikom, jak również ogranicza ryzyko zakażenia odwiedzających pacjentów.

\section{WNIOSKI}

Pracownicy i właściciele aptek są świadomi roli aptek otwartych w systemie opieki zdrowotnej w czasie pandemii COVID-19. Władze publiczne i instytucje rządowe powinny zwracać większą uwagę na bezpieczeństwo pacjentów w aptekach otwartych. Nie należy lekceważyć ryzyka, jakie stwarzają niewystarczająco zabezpieczone apteki otwarte. Należy poddać ocenie sposób reakcji na pandemię wywołaną SARS-CoV-2 i wyciągnąć odpowiednie wnioski, aby systemy opieki zdrowotnej były gotowe w razie wystąpienia nowej pandemii lub innego globalnego kryzysu.

Źródło finansowania: Niniejsze badanie zostało sfinansowane przez firmę Polska Grupa Farmaceutyczna S.A, numer grantu PGF/2/2020.

11. Ung COL. Community pharmacist in public health emergencies: Quick to action against the coronavirus 2019-nCoV outbreak. Res Soc Adm Pharm 2020;16:583-586.

12. Erku DA, Belachew SA, Abrha S, et al. When fear and misinformation go viral: Pharmacists' role in deterring medication misinformation during the "infodemic" surrounding COVID-19. Res Soc Adm Pharm 2021 Jan;17(1):1954-1963.

13. Karasneh R, Al-Azzam S, Muflih S, et al. Media's effect on shaping knowledge, awareness risk perceptions and communication practices of pandemic COVID-19 among pharmacists. Res Soc Adm Pharm 2021 Jan;17(1):1897-1902.

14. Carico R, Sheppard J, Thomas CB. Community pharmacists and communication in the time of COVID-19: Applying the health belief model. Res Soc Adm Pharm 2021 Jan;17(1):1984-1987.

15. Liu S, Luo P, Tang M, et al. Providing pharmacy services during the coronavirus pandemic. Int $\mathrm{J}$ Clin Pharm 2020;42:299-304.

16. Li H, Zheng S, Liu F, et al. Fighting against COVID-19: Innovative strategies for clinical pharmacists. Res Soc Adm Pharm 2021 Jan;17(1):1813-1818.

17. Hua $\mathrm{X}, \mathrm{Gu} \mathrm{M}$, Zeng $\mathrm{F}$, et al. Pharmacy administration and pharmaceutical care practice in a module hospital during the COVID-19 epidemic. J Am Pharm Assoc 2020;60:431-438.el.

18. New e-prescriptions in Poland. https://www. polskieradio.p1/395/7784/Artykul/2436223, Neweprescriptions-in-Poland. Published 2020. (accessed 17 June 2020) 
19. Hoti K, Jakupi A, Hetemi D, et al. Provision of community pharmacy services during COVID-19 pandemic: a cross sectional study of community pharmacists' experiences with preventative measures and sources of information. Int $\mathrm{J}$ Clin Pharm 2020 Aug;42(4):1197-1206.

Received:28.08.2020

Accepted for publication: 5.03.2021
Otrzymano: 28.08.2020 r.

Zaakceptowano do publikacji: 05.03.2021 r.

Address for correspondence:

Adres do korespondencji:

p.merks@uksw.edu.pl

Faculty of Medicine, Collegium Medicum, Cardinal Stefan Wyszyński University

Wóycickiego 1/3, 01-938 Warsaw, Poland 